\title{
Lexical Culture*
}

Reinhard Rudolf Karl Hartmann, University of Exeter, United Kingdom

\begin{abstract}
The paper focuses on the mutual relations between linguistics and lexicography. Against the background of etymology and comparative-historical linguistic studies and using the words 'lexical' and 'culture' as examples, an attempt is made to demonstrate the relevance of morphology, grammar and semantics to the description of vocabulary and its lexicographic codifica. tion. Issues of intralingual variety and interlingual diversity can now also be addressed within the theoretical framework of contrastive textology, supported by computer-aided parallel text corpus analysis. However, lexicography is not entirely dependent on the results of linguistic research; it needs to move on and develop its own theoretical base. Recent progress in four fields of dictionary research has indeed contributed to an international upsurge of 'lexical culture'.
\end{abstract}

Keywords: LINGUISTICS (ETYMOLOGY, MORPHOLOGY, GRAMMAR, SEMANTICS), CONTRASTIVE TEXTOLOGY (PARALLEL TEXT CORPORA), LEXICOGRAPHY (REFERENCE SCIENCE, DICTIONARY RESEARCH), CULTURE

Opsomming: Leksikale kultuur. In hierdie artikel word gekonsentreer op die gemeenskaplikhede tussen die linguistiek en die leksikografie. Teen die agtergrond van die etimologie en vergelykend-historiesé linguistiese studies en met 'lexical' en 'culture' as voorbeelde, word 'n poging aangewend om die relevansie van morfologie, grammatika en semantiek aan te dui in die beskrywing van die woordeskat en die leksikografiese kodifiëring daarvan. Kwessies van buitetalige verskeidenheid en intertalige uiteenlopendheid word ook aangespreek binne die teoretiese raamwerk van kontrastiewe tekstologie, ondersteun deur rekeneaargesteunde parallelle tekskorpusanalise. Leksikografie is egter nie heeltemal afhanklik van die resultate van linguistiese navorsing nie; dit moet verder vorder en 'n eie teoretiese basis ontwikkel. Onlangse ontwikkeling in vier velde van woordeboeknavorsing het inderdaad bygedra tot $n$ internasionale oplewing van 'leksikale kultuur'.

Sleutelwoorde: LINGUISTIEK (ETTMOLOGIE, MORFOLOGIE, GRAMMATIKA, SEMANTIEK), KONTRASTIEWE TEKSTOLOGIE (PARALLELLE TEKSKORPUSSE), LEKSIKOGRAFIE (VERWYSINGSWETENSKAP, WOORDEBOEKNAVORSING), KULTUUR

Lexical culture may be a newish phrase, but it is not a new phenomenon. Indeed, human curiosity in words and their ever-changing forms and meanings lies at the beginning of any scholarly effort to understand them. In this sense, the study of words surely predates linguistics as an academic discipline. Often it was triggered by the need to understand words in texts, in religious texts, in legal texts, and in literary texts, for instance. These are also, in many

Plenary lecture held at the 8th Annual Conference of ALASA, Stellenbosch, R.S.A., July 1995.

Lexikos 6 (AFRILEX-reeks/series 6: 1996): 184-198 
cultures around the world, the early forerunners of linguistic interpretation. To give just one example, from India, in the tradition of Sanskrit scholarship, where the exegesis of religious texts, namely the Vedic hymns, eventually led to the impressive linguistic work of Panini and other grammarians at least four centuries before Christ, producing a description of the structure of words which anticipated the rules of generative grammar by over 2,000 years!

In the Western tradition of linguistics, lexical interest was for a long time focussed on etymology, or the explanation of the origin of words and their change throughout the historical development of a language. This in turn led to the creation of historical-comparative linguistics, or 'philology', especially since 1786 when William Jones stipulated a genetic link between various socalled 'Indo-European' languages from Sanskrit and Greek through Latin to most of the modern Romance, Germanic, Slavonic and Celtic languages.

Knowledge of this kind shows us that our phrase 'lexical culture' has a Greek and Roman pedigree, lexical being derived from the Greek words lexis and lexicon which mean 'word' and 'word-book', respectively, and culture (literally) rooted in Latin culture which in turn comes from the verb colere 'to till' or 'cultivate'. Both lexical and culture are thus very old words with impeccable Indo-European family connections. If we had more time, we could go on tracing their historical evolution and their cognates in other languages; we would discover, and historical-comparative linguists and historical dictionaries such as the OXFORD ENGLISH DICTIONARY would assist us, that there are fascinating linguistic interconnections, on the one hand, between lexis in Greek with legein 'to read' and logos 'speech' and their cognates in other languages, such as Latin legere 'to read' and possibly lex 'law', and, on the other hand, between cultus in Latin with colonia 'settlement' and collum 'neck' and its cognates in other languages, such as Greek kuklos 'cycle', Middle Dutch hals 'neck' and English wheel.

Today, etymology is no longer academically very respectable, and historical-comparative linguistics is not in great demand in the universities, but most of the world's great all-purpose dictionaries still record lexical information of this kind, and their buyers and users expect to find it in them.

Meanwhile, the term 'derivation' has acquired a modern sense in addition to its historical one: since the middle of our century linguists seem to be less interested in the (diachronic) processes of lexical evolution, but rather more in the (synchronic) processes of word-formation: How are new words produced from the lexical resources of any one language, and how does 'borrowing', or copying, words from other languages work?

This is the province of morphology, the study of the structure of words in terms of the constituent parts that help to shape them, like roots and affixes, free morphemes and bound morphemes, and derivational and inflectional elements.

When we claim that we are now more interested in morphology than in etymology, we are perhaps also making value judgements about such things as 
scholarly solidity and historical uncertainty, even (I am exaggerating a little) declaring our preference for fact over fiction. When we say that the morphological resources of English allow the formation of adjectives like lexical and cultural from nouns like lexicon and culture, we are observing a regular pattern by inspecting data available to us all, which is an established principle of scientific methodology. However, when we say that English lexical, a word first documented in 1836, comes from lexicon, borrowed from Greek via Middle French in 1603, and is thus cognate with certain words in other languages, we also grudgingly admit (as does the BARNHART DICTIONARY OF ETYMOLOGY, 1988, from which I have taken this information) that datings depend on the accidental nature of the records on which they are based, and the evidence becomes more and more shaky the further back we go in time, and the more we have to rely on theoretical reconstructions.

Morphology is only one of several branches of linguistics; together with syntax, it forms the field of grammar which has dominated the scene for the last 40 years or so. Indeed, for part of this period it might be argued that there has not been a 'lexical culture', 'but rather a 'grammar culture' which has tended to relegate vocabulary to lists of items, regarding the dictionary merely as a collection of irregularities that cannot be explained by syntactic rules. One famous British linguist, John Lyons (1971: 514) put it like this:

We can regard the lexicon as a kind of appendix to the grammar - an appendix in which we find, appropriately indexed, all the information that we need to know about particular lexemes or their associated forms and cannot derive from anything else that the grammatical or phonological analysis of the language tells us about them.

By turning their focus of attention away from the lower-level constituents of words towards the higher levels of phrases, clauses and sentences, linguists were in danger for a while of losing sight of the basic lexical units altogether. By regarding words like culture and lexicon merely as instances of the syntactic category 'noun' and words like cultural and lexical merely as members of the word-class 'adjective', are we not missing a lot of essential features of these items? (This is one area where the so-called love-hate relationship between linguistics and lexicography could be potentially explosive.)

The aspect of language where 'grammatical culture' has overshadowed 'lexical culture' most is, of course, meaning or semantics. We have already seen how our two favourite words have changed historically and how difficult their interpretation can be. There are certainly multiple senses, as, with culture, we move from the cultivation of plants and animals (as in agriculture and - of special significance here in Stellenbosch - viticulture) to the cultivation of intellectual activities like art, music and education (think of phrases like high culture or cultured person), and on to further meanings as used in special fields like anthropology, biology and the media; cf. the entry culture in the OXFORD 
COMPANION TO THE ENGLISH LANGUAGE (McArthur 1992: 274).

To elucidate these various senses or meanings, we need a well-developed semantics. Unfortunately, as another British linguist reminds us (Cruse 1990: 139), semantics is still rather young and relatively unsophisticated:

It is probably true to say that the most influential work to date in semantics has been somewhat theoretical in orientation, and has been directed preponderantly towards elucidating and accounting for the logical properties of sentences within the framework of some system or other of formal logic. There has been relatively little in the way of descriptive work ...

Descriptive work is arguably just as important as theory, you will agree.

It might be argued that the descriptive semantics that linguists like Cruse are demanding has already been achieved by lexicographers who have always striven to supply explanations of the lexical units of the language in the form of definitions in dictionaries. There are even some specialised types of dictionaries available which provide such information, e.g. synonym dictionaries and thesauruses (like Laurence Urdang's excellent and original OXFORD THESAURUS, 1991, which arranges words of similar meaning in alphabetic, not thematic, order and gives example sentences to distinguish shades of meanings between them).

While such reference works undoubtedly exist, at least for the major languages of the world, they cannot meet all the various needs users might have, and they do not usually treat more than the core vocabulary, and that only superficially. So we must continue to encourage a two-way debate between linguistic semantics, on the one hand, and practical lexicography, on the other, about what needs to be done and what can be done to describe in detail the semantic behaviour of lexical items in the context of language use.

A number of theoretical approaches and descriptive techniques are available. From these, I can only briefly mention three.

The first is usually called 'lexical field' theory, or 'semantic field' theory, a way of analysing lexical items into conceptual sets or domains. This is associated with German linguists like Jost Trier and Walter Porzig in the 1930's; you may also have come across names like Baldinger, Geckeler, Lipka and Lutzeier. I myself have experimented with the cooking verbs, pipe fittings, and words like plane, level and stratum, but our words lexical and culture are still waiting to be described in detail (a good summary of this approach is Adrienne Lehrer's book Semantic Fields and Lexical Structure, 1974).

The second approach is labelled 'componential analysis' or 'distinctive feature analysis', the former being associated with American anthropology of the 1940's and 1950's, the latter with transformational-generative grammarians, notably Katz and Fodor who produced the famous example of bachelor broken down into its sense elements in the form of a family tree. There is also a Euro- 
pean version of this theory which goes under the name of 'structural semantics'; the most well-known instance is the analysis of pieces of furniture for sitting on, presented in the form of a matrix of columns and lines, with + and signs entered in the spaces, attributed to the French linguist Bernard Pottier.

The third approach I want to single out here is the much more recent offshoot of cognitive linguistics and psychology which is pursued under the banner of 'prototype semantics' and popularised by George Lakoff, Anna Wierzbicka and Jean Aitchison and applied to lexicography by Dirk Geeraerts. Geeraerts (1994) gives the example of trousers / pants / blue jeans and discusses some of the factors that determine their respective salience and variation in particular contexts.

Two aspects are often overlooked when these semantic issues are debated, and I have spent many years of my career trying to draw people's attention to them: one is intralingual variation, the other is interlingual contrast. It surely matters, I would have thought, whether a semantic description is done not only for the purpose of establishing the similarities and differences between the analysed lexical items in question (as the three approaches that I have mentioned try to do), but also to check if the style, register or text type in which they typically occur have an impact on the relations between them. Thus, a word like culture does not have a single or basic meaning, but various uses in communicative situations. So in the discourse community of social history, culture is often synonymous with civilisation, while in political texts it can mean 'race' (think of the phrase multicultural society), while in medicine the term culture can be paraphrased by something like growth of micro-organisms.

The other factor in semantic description apart from intralingual variation is interlingual contrast. As we all know, there is no such thing as straightforward one-to-one lexical equivalence, especially between pairs of languages which are not genetically related, and this causes great difficulties in translation, a process with which I am sure most of you are familiar. If you are, you will also be aware of a particularly problematic aspect of this interlingual matching, or lack of fit, namely what is commonly referred to as 'culture-specific vocabulary', or those lexical items that are used to label things, concepts and institutions unique to a particular society. This is an area where linguists sometimes give up, and leave the field completely to ethnographers, translators, and bilingual lexicographers (cf. Hartmann 1992).

While admittedly these problems of intralingual variation and interlingual contrast seem at times unsolvable, we must not lose heart, and indeed help seems to be at hand, both theoretically and practically. In a book which I published 15 years ago, entitled Contrastive Textology (Hartmann 1980), I made out a case for an integrated approach to this problem. I saw it as the combination of intralingual variety studies or discourse analysis and interlingual contrastive analysis (hence the term 'contrastive textology' which unfortunately has not caught on, although the desirability of such an approach has since been acknowledged by other linguists, too). Contrastive statements about a pair of 
languages only make sense if they are based on the analysis of so-called 'parallel texts', defined as examples of discourse from corresponding genres. This has remained a theoretical demand or dream as long as we have not had the means to carry it out on a large scale.

Today, computer technology gives us the opportunity to attempt a new generation of contrastive text linguistics for the benefit of semantics, translation and bilingual lexicography. I cannot go into the intricacies of 'corpus linguistics', as the literature is too complex to review and the operational procedures are too diffuse to present here. Let me just hint at the essentials. The recent boom in monolingual text corpora, especially of English, has tended to minimise interlingual or crosslinguistic work, although even monolingual corpora can have a contrastive dimension when they give us data about different regional varieties (such as British vs. South African English), about intralingual registers (such as spoken vs. written), or about different periods of the same language.

It is extremely difficult to get a good overall picture of the field of bilingual text corpora, as their scope and design features vary according to whether they are intended for linguistic description, foreign-language teaching, bilingual lexicography, human translation, machine translation, artificial intelligence research, or speech technology, and reports are scattered over very diverse periodicals and conference proceedings. I find it helpful to distinguish two types of parallel texts: 'bitexts' or translationally matched texts (such as European Union reports and laws and their translated versions in other languages), and 'paired texts' which are independently written texts from two languages, but matched in terms of similar communicative settings (such as the manifestoes of the political parties in Britain and Germany). Interesting work has been done, both on aligned bitexts and on matched paired texts, to extract lexical equivalents, which is a promising technique of potential benefit to translators and bilingual lexicographers.

May I end this section by presenting a brief illustration of what I have done on an English-only text corpus with our two words lexical and culture. One of our students on the Exeter M.A. Course in Lexicography, Lucia Cortese, recently enjoyed a practical placement at COBUILD in Birmingham. I asked her to check and print out all occurrences of the two words, lexical and culture from the 'Bank of English' corpus of over 200 million words. The material came, by fax, laid out in the form of concordance pages, with the words in question in a central column together with preceding and following context line by line. You will be interested to know that there were 81 citations of lexical and exactly 100 citations of culture. (See appendix.)

The fact that the two words did not occur together, not even once, simply means that the corpus has no record of the phrase lexical culture, and if it does not occur in a large corpus, the likelihood is that it may be a nonce-formation. (If my paper had been processed in Birmingham, Lucia would of course have found quite a number of instances.) The concordance printouts in the 
Appendix tell us a number of facts about these two words and their collocations that we could not have predicted simply from native speaker intuition alone, e.g. that lexical collocates most frequently with nouns that it modifies, such as database and item, while culture rarely forms noun compounds as first item (in such phrases as culture gap or culture studies; culture shock, surprisingly, was absent), but often forms the last element in collocations like our culture, French culture, working-class culture, nature and culture, civic culture, black culture, post-modern culture, and lesbian culture.

Before I move on to more strictly lexicographic topics, let me briefly check over the ground we have covered so far. We started by looking for evidence of 'lexical culture' in linguistic studies. We found some in etymology and historical-comparative linguistics, and in the dictionaries inspired by these diachronic perspectives. As we went forward into the structural linguistics of our own century, we saw the emergence of the pioneers of semantics (such as lexical field theory), and also some progress in the field of morphology. But we also noted that during the period (after the 1950's) of the predominance of grammatical theory, linguists pushed lexical considerations to one side. Now, the pendulum has swung again in the other direction, and we can observe further advances in semantics, including contrastive studies, in discourse analysis, in computational linguistics, and in psycholinguistics.

Today, there is a greater willingness on the part of linguists to acknowledge their indebtedness to dictionaries as repositories of lexical knowledge and codification, and on the part of lexicographers to utilise ideas and techniques supplied by linguists. However, while I am stressing this increasing two-way traffic, I do not believe that lexicography is only dependent on progress in linguistics; lexicographers need to develop their own institutions and theories which are appropriate to their specific requirements, and also borrow from other fields such as information technology.

The terminological distinction that is sometimes made between 'lexicology' and 'lexicography' can be misleading. Lexicology, where it is recognised as such, is a branch of linguistics dealing with aspects of the vocabulary (historical, morphological and semantic). Lexicography is not merely applied lexicology, but a related set of lexically based activities which has its own theoretical premises and professional practices. And a lot of these are not 'linguistic' even, so much so that among some of my colleagues we have recently been talking in terms of a wider context of 'reference science', which would include the theory and practice of making reference works of all kinds, including encyclopedias, maps, directories etc., by reference professionals, for the benefit of a variety of users with a variety of reference needs and reference skills (we note, in passing, that 'reference' in this wider sense is only partly connected with the sense in which it is used in semantics).

May I, in the final section, venture a few thoughts on the state of this field of lexicography which I see as being positioned within a wider reference perspective, but still as part of 'lexical culture'. Dictionaries and all other types of 
reference works are indeed cultural products serving cultural purposes, which is why the famous French lexicographer Alain Rey - who is also interested in encyclopedias and in intercultural translation - calls the general-purpose explanatory dictionary 'le dictionnaire culturel' (Rey 1987), and why the most recent volume of the Lexicographica Series Maior, a festschrift in honour of the Czech-American doyen of lexicography, Ladislav Zgusta, has the title Cultures, Ideologies and the Dictionary (Kachru and Kahane 1995).

I have been very fortunate in my academic career to be associated in a modest way with the rise and establishment of lexicography as an interdisciplinary and international field. Exactly 30 years ago, in the title of one of my first review articles, I asked the deliberately provocative question "Is lexicography making progress?" (Hartmann 1965). Today such a title would be quite unthinkable in the light of all the associations, conferences, journals and other publications on the subject (cf. the International Encyclopedia of Lexicography edited by Hausmann et al. 1989-91), in addition to the flood of dictionaries and other reference books on the market world-wide.

But this growth has been uneven, and some of the progress on the theoretical side of lexicography has been an uphill struggle, I must admit. During my 20 or so years at Exeter, a small provincial university in the county town of Devon in Southwest England, I managed to organise five meetings that have made a contribution to progress by bringing like-minded people together, in 1978 at the Lexicography Seminar of the British Association for Applied Linguistics, in 1980 at the International Summer School on Applied Linguistics and Dictionary Making, in 1983 at the LEXeter Conference on all Aspects of Lexicography (which also became the first EURALEX Congress), in 1986 at the Seminar on the History of Lexicography, and in 1989 at the Workshop on Lexicography in Africa, all with published proceedings. In 1984 we established the Dictionary Research Centre, and since 1987 we have run 10 international oneweek courses in Lexicography called InterLex.

Encouraged by the success of all these events, we explored the idea of mounting a European diploma course at Master's level, which we designed with the help of an ERASMUS grant and a consortium led by people at Exeter, Lille and Amsterdam. This M.A. in Lexicography is now in its fourth session. The subject of training is of course fraught with limitations and laced with compromises, but the course attracts half a dozen students each year (from almost as many different countries) who all manage to obtain a practical placement with a dictionary publisher.

My involvement with all these ventures, with the Lexicographica series, and visits at centres in other countries has given me an awareness of the possibilities of the field, but also of the enormous differences between the various national, linguistic and cultural traditions. The results of a survey I attempted of the lexicographic scene in Europe was published in Lexikos (Hartmann 1993). Before that, I had published the papers of a modest workshop on lexicography in Africa (Hartmann 1990). After my 1995 visit to South Africa I am in a much 
better position to compare notes and see where the real differences lie in terms of lexicography between Europe and Africa.

Finally, a few words about my view of four aspects or branches of 'dictionary research', as I prefer to call the enterprise of metalexicography.

The lexicography of a country or language depends not only on the external history of that country or language, but also on the internal cultural traditions that help to shape successive generations of dictionary-making. It is therefore imperative to explore all facets of dictionary history (cf. Hartmann 1986).

Another aspect of dictionary research is dictionary typology, or the classification of the many genres of reference works that we find in various periods, countries, or cultures. Of the many types that we have studied at Exeter, the 'bilingualised' learner's dictionary has offered some intriguing new features (cf. Hartmann 1994).

Innovation may occasionally come from dictionary criticism, a relatively old field which has been bedevilled by prejudice and arbitrary personal opinions. More recently, attempts at rational evaluation of dictionaries against sets of more objective standards have shown promise (cf. Osselton 1995).

All these branches of dictionary research can profit from an empirical look at dictionary users, their reference needs and reference skills which originally cause and ultimately test the compilation of such works. Several postgraduate projects at Exeter have made significant contributions to this field (cf. Diab 1990, Stark 1990).

In conclusion, I would like to say that I am optimistic, both in terms of the 'lexical culture' that is building up in the relations between linguistics and lexicography, and the way lexicography is being established as a respectable discipline. The future looks bright, but having recognised this lexical culture, we must nurture it in every way we can. This includes attention to training, to more ambitious research, to better documentation facilities, and to more intensive contacts between people, disciplines and countries around the world.

\section{References}

Cruse, D.A. 1990. Language, Meaning and Sense: Semantics. Collinge, N.E. (Ed.). An Encyclopedia of Language: 139-172. London and New York: Routledge.

Diab, T. 1990. Pedagogical Lexicography. A Case Study of Arab Nurses. Tübingen: M. Niemeyer.

Geeraerts, D. 1994. Varieties of Lexical Variation. Martin, W. et al. (Eds.). EURALEX 1994 Proceedings: 78-83. Amsterdam: Vrije Universiteit.

Hartmann, R.R.K. 1965. Is Lexicography Making Progress? The Incorporated Linguist 4: 42-45.

Hartmann, R.R.K. 1980. Contrastive Textology. Comparative Discourse Analysis in Applied Linguistics. Heidelberg: J. Groos.

Hartmann, R.R.K. (Ed.). 1986. The History of Lexicography. Amsterdam: J. Benjamins.

Hartmann, R.R.K. (Ed.). 1990. Lexicogtaphy in Africa. Exeter: University of Exeter Press. 
Hartmann, R.R.K. 1992. 300 Years of English-German Language Contact and Contrast: The Translation of Culture-specific Information in the General Bilingual Dictionary. Blank, C. (Ed.) Language and Civilization. A Concerted Profusion of Essays and Studies in Honour of Otto Hietsch: Vol. II, 310-327. Frankfurt: P. Lang.

Hartmann, R.R.K. 1993. General Lexicography in Europe. Lexikos 3: 67-82.

Hartmann, R.R.K. 1994. Bilingualised Versions of Leamer's Dictionaries. Fremdsprachen Lehren und Lemen 23: 206-220.

Hausmann, F.J. et al. (Eds.). 1989-91. Wörterbücher / Dictionaries / Dictionnaires. An International Encyclopedia of Lexicography. 3 volumes. Berlin: W. de Gruyter.

Kachru, B.B. and Kahane, H. (Eds.). 1995. Cultures, Ideologies, and the Dictionary. Studies in Honor of Ladislav Zgusta. Tübingen: M. Niemeyer.

Lehrer, A.J. 1974. Semantic Fields and Lexical Structure. Amsterdam: North-Holland.

Lyons, J. 1977. Semantics. 2 volumes. Cambridge: U.P.

McArthur, T. (Ed.). 1992. The Oxford Companion to the English Language. Oxford: U.P.

Osselton, N.E. 1995. Chosen Words. Past and Present Problems for Dictionary Makers. Exeter: University of Exeter Press.

Rey, A. 1987. Le dictionnaire culturel. Lexicographica International Annual 3: 3-50.

Stark, M. 1990. Dictionary Workbooks. A Critical Evaluation of Dictionary Workbooks for the Foreign Language Learner. Exeter: University of Exeter Press. 


\section{Appendix: COBUILD concordances of 'lexical' and 'culture'}

[The author is grateful to COBUILD, Birmingham, for permission to reproduce these concordances, and to Lucia Cortese for obtaining them.]

<t) Another alternative is to work toward some sort of those of assigning different weights and of establishing the process of picture classification bypasses any whereas when names for pictures have to be found, by technical terms, and it has had its intrinsic follows a different route. It does not specially involve s work with Generalized Phrase Structure Grammar and Criseyde's heart and the weakness of women: an essay in they know \# I'm the last person to try and trap rap in a Cobuild. Collins and Birmingham University International I think $\langle\mathrm{ZF} 1\rangle$ the $\langle\mathrm{ZFO}\rangle$ the target skills are control of er of the language in context. Target skills control of perhaps you use in your teaching the concept of linked $s$ very useful for them to have basic concentration at a neatly into the model that I'm proposing for our new $\langle Z G Y>$ So stage one we chose erm a few of the commonest how $\langle Z F 1>$ what $<Z F O>$ what we found $\langle Z$ ZY $>$ very common $s$ true but why don't I just out all my $\langle Z G Y>\langle M O X>$ Which $Z G Y>$ publisher $<Z G Y>$ etcetera and you've got a $1+$ a new database which contains ei erm information pertaining to for us phonetics will be one relation within that new or er corpus would have er erm a field anyway in the thing the figure in the erm $<F O X>M m$. $<M O X>$ er we for instance added in some of the fields of the old a $<$ ZFO $>$ a $<Z$ ZFJ $>$ s $+<Z$ ZFO $>$ starting point for that new again one thing that the [pause] that $s+$ possible new pause] FX you were wanting some information from the old it more than once? $<M O X>\langle Z G Y\rangle\langle M O X>$ Can you use it for a times $\langle Z G Y\rangle\langle M O X\rangle\langle Z G Y><M O X\rangle$ The admin database the except possibly having a syntax field in the new data on a grammatical basis. $<F O X>$ Yes. $<M O X>$ We only have $\mathrm{Mm}<<\mathrm{FOX}>$ going to be a massiver thing than the original connection between lexis [pause] and what they're doing. might be a good idea to do it both for sort of erm fully

$<Z G Y>$ in the gr in grammatical ones \# $\angle Z F 1\rangle$ In $\langle Z F O\rangle$ in CZF1> I've <ZFO> I've begun looking at these er semicould think of them as being on the borderline between ought to do if it was $<M O X>$ You'd think. $<M O X>$ a typical a class they're it's $\langle Z G Y>$ that gets increasingly more lexical

lexical

lexical

lexical

lexical

lexical

Lexical

lexical

lexical

Lexical

lexical

lexical

lexical

lexical

lexical

lexical

lexica

lexical

lexical

lexical

lexical

lexical

lexical

lexical

lexical

lexical

lexical

lexical

lexical

lexical

lexical

lexical

Lexical

lexical

lexica

lexical

lexical

lexical

lexical. ordering of planes in accordance with general moral priorities are undeniably hard to establish and or logogen system, whereas when names for pichures search and retrieval will become necessary." If this and syntactic productivity exploited by Hegel and changes, nor syntactic changes (as with Hegel), though -Functional Grammar.Frederick Newmeyer, Linguistic interpretation", Studia Neophilologica, vol. 54 ( ghetto of \# Yo!" and \# Hey, motherf \# er!" but, Database run by MX. A computer fed each week with items ex and control of structural items \# $\angle Z F 1>$ The items control of structural items task type text items which in the kind of description I use is called level when they've actually taken part $\langle Z G Y\rangle$ in a database. [laughs \# $<F O X>M h m<F O X>$ We can't talk items in the languages. This was because many of our items $\angle Z G Y>$ Then from that experience we deliberately realization $<Z G Y><F O X>$ Cos you dan't know the cost database which contains ei erm information pertaining items. And this is where some of the points that have database which could also contain (pause \# information database. How much more information was added to it database would be updated. Erm [pause] and that would database which you were interested in for instance a database the sooner it can be circulated to other database would have is actually all the attested forms. database weren't you. $<F O X>$ Have we done five? $<F O X>$ database $\langle Z G Y\rangle$ use it as a $\langle Z G Y\rangle\langle M O X\rangle$ Yes. $\langle M O X\rangle\langle Z G Y\rangle$ database $\langle\mathrm{MOX}\rangle\langle\mathrm{ZGY}\rangle\langle\mathrm{MOX}\rangle$ the grammar database. $\langle\mathrm{MOX}\rangle>$ database which connects with the tagger there is no

$<F O X>$ Yeah. $<$ MOX $\rangle\langle Z$ ZGY $>\langle F O X\rangle$ But this grammar database database $\langle M O X>$ Yeah that's why I said link not $\langle Z F 1>$ I items must be mentioned at some point in what they're passives $\langle Z G Y\rangle$ and for those and then together. $<M O X\rangle$ ones you can start off with the basic frequency of the er cohesive items like stuff and thing. Perhaps we

cohesion and substitution $\angle M O X>$ Yeah. $\angle F O X>$ in which item in a nom+<FOX $>\mathrm{Mm}<\mathrm{MOX}>$ at the end of a nominal $<M O X>$ Yeah. Yeah. $\angle F O X>$ Yeah. $\angle F O X>$ Yeah. $<M O X>$ So I mean 
$<$ ZF1 $>$ in $+<$ ZFO $>$ includes some kind of considerable er word". A difficult word. That's straight lexis you know by one in doing <ZGY> as well as a bit of syntactic and tagging system. This assigns a part of speech to every suite. This assigns a semantic tag or tags to every tag set was loosely based on Tom mcarthur's Longman pause \# $\angle \mathrm{M} 01>$ So the system's lexicon consists of the match is not found the system tries to match on the tag the words for the category. $\langle$ MOX $>\langle Z G Y\rangle\langle M 01\rangle$ Every $\langle$ MOX $\rangle\langle Z F 1\rangle$ That $\langle Z F O>$ that's $\langle Z F 1\rangle$ the the $1+<Z F O\rangle$ the Yes. Yeah. $<M O X\rangle$ Well in this case er $\langle Z F \mid\rangle$ the $\langle$ ZFO $\rangle$ the sixty-one doesn't it the that we always said that a $r+\angle Z F O>$ the reigring wisdom in this field of really er subtle ways in the way meanings are woven into their the twiddly bits are missing. okay what you've got is Mm. $<\mathrm{FOX}>$ Things like well they re not sort not very Mm $<$ FOX $>$ Things like well they re not sort not very
notion of collocation where they were $1+$ collocates with $<Z G Y>\langle M O X>$ And putting what appears to be the strongest

would be to start off with the sort of fairly infrequent that I want to be sure I get in that are reasonably

often than that one or whatever. I mean they will accept numbers $<Z$ ZF1 $>$ but [pause] $<Z$ FO $>$ but we just had to use that $<Z G O><M O X><Z F 1>$ Phase $<Z F O>$ phase three was the $\langle Z G Y>\langle M O X>$ Ah yes. Yes $\langle Z G Y\rangle\langle M O X>$ Oh and the $\langle Z F 1\rangle$ yes. Yes $\langle Z G Y><M O X>O h$ and the $\langle Z F 1>$ lexical et $\langle Z F O>$ up $<Z G Y><M O X><Z G Y>M X ' s<F O X>$ That's right and the that would hold several others and say okay what other up. $<M O X>$ Well we've got bits and pieces of that in the word list by taking stuff out of $\angle Z F 1>$ the $<Z F O>$ the old
database software are we going to be able to use the old stage of the kind of things we were putting in the this is part of what I'm hoping to build into the new a lot $\langle Z G Y>$ in the dictionary $<M O X>$ There's a lot in the state $\angle Z G Y>$ you know being an $\angle Z G O>$ arrangement of lexis out of the grammar. Er cobuild is a programme in

been $\langle Z G Y>$ expressed $\langle Z G Y\rangle$ as stomachache as a single although obviously it's the $\langle$ ZF $1>$ same $\angle Z F O>$ same $<M 02>$ Yeah. $<M 04>$ The minimum is eight. $<M 03>$ Right.<F01> $<t>$ And there are individual freaks. Navaho makes no

ail roti sous la cendre aux petits oignons noveaux. $<b$ Whatever the meaning intended for this tern its Siemens, the German electronics company, have shown that lexical

lexical

lexical

lexical

lexical

Lexical

lexical

lexical

lexical

lexical

lexical

lexical

lexical

lexical

lexical

lexical

lexical

lexical.

lexical

lexical

lexical

lexical

lexical

lexical

lexical

lexical

lexical

lexical

lexical

lexical

lexical

lexical

lexical

lexical

lexical

Lexical

lexical

lexical additions so that $<F O X>$ Yeah. $<M O X>$ it's not purely a problems.Nice to see it's there anyway. Hard words process. It's that sort of description is what these item or syntactic idiom in a text using probabilistic item in the text as you will see on the ZZGY> fourth and Contemporary English which may be familiar to some item together $\langle Z F 1\rangle$ with its $\langle Z F O>$ with its syntactic item alone without the syntax tag as probabilistically item. $<M O X><Z G Y>$ cuntent $<Z G Y>$ are super categories realization of what Ive been feeling a need for in work is running in parallel because erm on Monday erm set is not a set of words that go in the same

semantic development er a lot more things are learned and grammatical structure. So presumably children are categories. You don't have any functional categories. words like theirs and what's and your and $\angle M O X>M m$. items $<F O X>M m .<M O X>$ so we wanted wrong idea and wrong item as the collocate $<F O X>$ Yes. $<M O X>$ but putting in items that I thought well no first of all I'd take the

There's not many actually because <ZF1 > most of the frequencies quite happily and accept that everyone items basically didn't we. $<M O X>$ Yeah.pause \# $\angle F O X>$ syllabus for the Cobuild English Course. $<M O X>$ As well er $<$ ZFO $>$ lexical syllabus of course $<M O X>$ Right. $<M O X>$ syllabus of course $<M O X>$ Right. $<M O X>$ has a few erm syllabus has the $\langle Z G Y>$ something $<Z G Y>$ as well hasn't $<M O X>$ That's right. $<M O X>$ items figure in this database haven't we. I mean if you coded a word list database you'd find which ones figured in which database in database format rather than the kind of database of you know er category of er $V$ plus this database which is information at every word form of database as well yeah. $<F O X\rangle\langle Z G Y\rangle$ of course $\langle Z G O\rangle$ Erm and $<Z G Y>$ phonic $<Z G O>$ equivalences. Hey nonny nonny computing or it was when you started er and therefore item and wouldn't be spelt with one word $\angle Z G Y>$ er but item.<MOX $>$ Isn't there a problem with hurt that the information write dictionaries and generally make lots distinction between blue and green, while literary dressings:preface gustative $=$ entree petale $=$ tranche ( make-up involves an incongruity: the seeming claim analysis \# looking up the existence of a word in a 
that in 1914 died violently, passing into some other that has been learned from the animal and tissue his visit is far less infuential for them than its orthodoxy but as true sacramentally-imbued pastors that It was getting hotter, and desert was spreading and the guests' problems on your own. Other expressions of the be $\langle\mathrm{FCH}\rangle$ given $\langle\mathrm{FCH}\rangle$ meaning. Much of what we call her own embryos, one after the other, to places of

and freedom Gayle and David are an example of how this to the surface. There's a rhythm of change in a

by its adherents in the historical setting of Westerm stirring the pot will cook up an ever more vibrant civic Fri. 7:30 p.m.Having a Wonderful Time (1938) A Speaking to foreign journalists, the deputy minister for Jovic called for an .. for .. bilateral ties in the .. and belongs to a new class of virus. Now they want to and they are as much a part of Greek history and

into Europe they brought with them a more sophisticated lover valuable increases her value. In a materialist touch with the pop music, the mini-skirts, the teenage the absence of correspondence between polity and Random House) Almond, G. and Verba, S. (1963), The Civic which Weber carved out a position for himself within culture Weis (1985, p. 7) adopts a hegemonic view of Clearly, the majority of people within almost every in to what we know today as Sanskrit. The Indo-Aryan 100 people whose language one does not speak and whose an economic base".As Worsley remarks, 'the concept of abilities: some effects of age, schooling, and

educationalsystem; in the urban context, this peasan consequently in tension with Bellah's view that American

acknowledges that an alternative to the prevailing

$<\mathrm{LTH}>$ PHOTO WTTH CAPTION \# <LHH > The Capital of French as Cermanophiles, following happy experience of German

direct about what they want or need. It's part of the world hotels make an irritating nod towards the local this as a poignant symbol for the fate of Tibet's living were writers of fiction or poetry, representative of a culture culture Culture Culture culture culture, culture culture culture culture culture. culture, culture culture culture, culture culture culture culture, culture culture,

Culture

culture,

culture

culture

culture

culture

culture culture", culture culture culture Culture culture culture. culture, culture

culture whose form is still unclear to us. Think of its studies, in order to determine the maximum tolerated One planners think it is. $<D$ American Catholics in one leaders make themselves welcome in Culture Two and they had lived by for three thousand years was failing like Feldman's complaint policy and his declarations and civilization consists in efforts people have made. and edification. Jesse, Woodson, James, and Frank were -wide pattern works. For the past five years, Gayle has where you push, then you pull back a little bit and His concern with social and political questions led to improving the quality of life for us all. Those of us seeking typist vacations at a mountain resort and of the Afghan government said that the foreign educational, scientific, technical and border it in the laboratory.<h> THE FARMING WORLD 1622british as the Hellenistic majority. There are small and than the Neanderthals had \# And this may certainly this kind of thinking is common. How does one know of the $1970 \mathrm{~s}$. Her peers were for the most part inherent in Canadian audiences' consumption of United (Princeton, NJ: Princeton University Press).Althusser, with which he effected his own insertion into

which sees culture as semi-autonomous (Gramsci, 1971). no longer believe that the only true experience of was decidedly patrist, evidence of ancestor-worship of one does not understand should not be underestimated has been virtually ignored by those social scientists International Joumal of Psychology, vol. 14 (1979), writ large would become the essence of the modern and society are tending towards individualism and exists. Already in the early 1970 s, ideas were and Commerce <LTH > Paris is indisputably one of the in Oberammergau and Salzburg,but came away imbued with You'd be amazed at how many people call us in but Peter Muller, the Amandari's brillant architect. or that of china's occupation will be dependent in that has diversity of age, colour, class, cultural 
of any formal education and his public championing of a have always used it as the language of literacy and invite the Japanese in. It'd wipe out any remaining weren't enough) of how much Elvis looted from black Hackney Homeless tent, things get slicker. YOGHURT to make things better. $<\mathrm{LTH}\rangle\langle\mathrm{LHH}\rangle \mathrm{LEO}<\mathrm{LTH}>$ The call of Programmes were removed from the Ministry of Sport, not sufficiently attuned to the new Council's \# business but our main concem is to set about creating a lesbian muscles (or lack of them). And for women who mix in a and audience a lesson in the evils of a Euro-centric short, there is emerging a global mass button-thumping Roots, an anthology of gay history, sex, politics and where contact with the modem African-Caribbean

10.30-m \# <KPD> $4.80<$ KPD> 3.50 concs). <LTH > QUEER the power to create laws that promote its language and Muslim country or a country of completely different has taped a message for the American people \# Iraq's $<\triangleright$ Audio footage of an Indian chant)<r> Berkes: Our series on the family \# In the last few decades, American 9205050211 UKRAINIANS STRUGGLE TO REGADN IDENTITY UN, class, and Gwen Macsai's hilarious send up of our body what else are we rissing out on in terms of Japanese

You know, there's no doubt about it \# I call this a Schneiderman (Medical Ethicist): Maybe we are in

but- < $>$ IRENA BUDO, Hungarian Teacher in Ukraine: In is where it's at the city's where we live that's and our were so integrally connected with westem history and

have written about the concept of organizational major focus of my P H D is to look at this concept of you think that's due to nature or due to culture. $<F O X>$ of this year, examining almost every aspect of Jewish life to the city is now regarded as history, as museum before 1995, said meaningfully: 'It's a question of that created the world's greatest free enterprise state and military zone, and their ancient Buddhist

done. Bloom in particular saw that transmission of the 20 outlets are planned by 1995 . < > But bridging the culture culture,

culture,

culture.

CULTURE

culture

Culture

culture

culture.

culture

culture,

culture

culture

culture

CULTURE

culture

culture

culture

culture

culture

CULTURE

culture

culture?

culture

culture

culture

culture

culture

culture.

culture

Culture.

culture

culture,

'culture

culture

culture

culture

culture of loud and loutish $C 2$-ishness. This finds its most and in Pakistan, where the mother tongues of the vast but they'd make the air breathable." <LTH> Are you The photo selection is good (if not better) than most are about smooth grooves, the mood of Motown soul and is very strong for Leos this week. In fact you could Youth Affairs to the Ministry of Education. and to work for Westminster. No thought is given to their From the start we have organised discussions, where it's 'in' to reveal breasts, the string vest is

Everyone cheers, and you can't help but wonder if she, with inane, if not regressive values, and we continue presents a wide range of essays and a troubling amount a mixture of fascination and revulsion. $\langle\mathrm{LTH}\rangle$ Those \# The Future of Lesbians and Gay Men in Theatre and \# If approved by lawmakers in Canada's 10 provinces, \# Oh, I have to tell you that the level of knowledge and information minister says Iraq has officially is important, one boy tells us later, we're proud of has changed quite a bit \# The American family has Noah Adams, host $<b$ The vote for independence in the told me why \# Thanks, Gwen \# By the way, I am an avid $<\rightarrow$ Reid: Well, there are really some good movies-

war \# We're kind of, you know-there's an old of cure rather than in a culture of care \# This is a and in democracy - < $>$ Ms. SZOLVACI: But spiritual and our lives basically are linked to cities now in that in fact it was impossible er for those resources Im thinking of books like In Search of Excellence and see how it can be applied in a more rigorous $<M 01>$ Right. Right. Thank you pause $<$ FOX $>$ I think we but ignoring the Holocaust. This omission, highly then all Glasgow is diminished. $<b$ The Second City in Europe, not European culture \# Aaah .. $<t>$ It should appear here, beneath the myth he was himself so destroyed or driven into exile. Stalinism and narism is the rock upon which liberal democracy might gap is not always without its problems. < t In Hong 
firms or launching their own businesses where male And Major, the man who was railing against Britain's yob for stifled entrepreneurial vigor. The political developments in technology and to our accelerated Among the infinite echoes of our sorry post-modern the sixties, he averred, his view of the emerging new hands in apocalyptic horror at the dangers of American owed much to the same kind of argument. Working-class Charter of 1955, which did indeed call for 'the doors of That book was subtitled Tales for an Accelerated live here among ourselves to defend our history and our the garden as a site for the interaction of nature and rather the part that can be absorbed, let us call our own grammar, and computers, too. We are going from a was to exterminate his people, their religion and their in the powrer to make proposals on healtheducation and You can take individuals and scatter them into another cheeks. For Filipinos, superstitious and sentimental by many Jews, the middle-class ones often embraced French to be exposed to television programs which reflect our keys in locks to language, music,geography, maths and for a variety of disciplines.In Aboriginal art and while showing off to the world, but he can't destroy our her whole life as an Aborigine out of touch with her own culture culture culture

culture.

culture,

culture

culture,

culture

culture

Culture.

culture."

culture,

'culture

culture

culture;

culture

culture.

culture,

culture.

culture,

culture.

culture

culture,"

culture does not dominate. $<\triangleright$ In my experience, however, a month ago, was there to get what turned out to be that created the conditions in which crack selling is

But within what remains of that shabby, embarrassing anything and nothing goes. Everything around us is would have been brighter.<b Peter Hall, on his Royal while at the same time enjoying a passionate love was inherently racist, officers would say. Once the to be opened to all \# thus placing culture, however In the novelty of that description, and a narrative A project that they obviously feel Le Pen can help and incorporates fossils, skulls, encrusted tools and acquisition device". That means I can line it up with dominated by literal logic to a culture in which there and he called for an international commission to (though only their cross-border aspects) and on If you take a Japanese or a Chinese and you dump him the era of 'Steady Eddie' has started well. $<p>$ That As early as the 1920 s several Jewish women there our multiculturalism, our ethics and our values She said the school, established in 1978, aimed to lessons for nine to 12-year-olds, they11 learn about he said. He can try and make us go to discos and in a society which largely ridiculed and rejected her 